\title{
Examining the perceived value of extracurricular enterprise activities in relation to entrepreneurial learning processes
}

\begin{abstract}
Purpose

This study contributes towards increased understanding of the perceived value of extracurricular enterprise activities from an entrepreneurial learning perspective. Past decades have witnessed a global increase in the provision of enterprise and entrepreneurship education alongside a growing suite of extracurricular enterprise activities. However, there is a paucity of research examining how entrepreneurial learning might be understood in the context of these activities.
\end{abstract}

\section{Methodology}

The study draws on an empirical study of student and educator participants across 24 United Kingdom (UK) universities using semi-structured surveys and in-depth interviews. Three main learning theories drawn from the entrepreneurial learning literature; experiential, social and self-directed learning provided a conceptual framework to frame the research phenomenon.

\section{Findings}

Findings posit that extracurricular enterprise activities provide perceived value in the experiential and social learning opportunities afforded for students. However, these activities are restricted in enabling the experiential learning cycle to be completed due to limited reflection opportunities. Positioning these extracurricular activities outside the main curriculum also empowers participants to self-direct aspects of their learning and develop their autonomous learning capabilities.

\section{Originality/value}

The existing literature focuses upon the entrepreneurial learning processes of established entrepreneurs rather than latent and nascent entrepreneurs within a Higher Education (HE) setting. The limited literature examining HE entrepreneurial learning does so by concentrating upon entrepreneurial learning resulting from in-curricular activities. This study offers novel insights into students entrepreneurial learning processes, highlighting the importance of experiential, social and self-directed learning opportunities to the entrepreneurial learning process and the perceived value of extracurricular activities as a platform for these types of learning.

Keywords: enterprise education; entrepreneurship education; entrepreneurial learning; extracurricular activities 


\section{Introduction}

Recent decades have witnessed a significant increase in the provision of enterprise and entrepreneurship education across universities (Bae et al., 2014; Nabi et al., 2017; Barnard et $a l ., 2018$ ) with over 3,000 such courses globally (Kuratko, 2017). There remains contention regarding how to define enterprise and entrepreneurship education and the difference between the two (Kuratko and Morris, 2017; Neck and Corbett, 2018). Although this issue is not explored here, the widely accepted QAA (2018) definitions are used to frame this UK based study. Therefore, enterprise education is defined as:

"the process of developing students in a manner that provides them with an enhanced capacity to generate ideas, and the behaviours, attributes and competencies to make them happen" (QAA 2018, p. 9).

Entrepreneurship education defined as "the application of enterprise behaviours, attributes and competencies into the creation of cultural, social or economic value. This can, but does not exclusively, lead to venture creation." (QAA, 2018, p. 7).

While there are distinctions as outlined above between enterprise and entrepreneurship education there is also significant overlap in the manner in which they are designed and delivered. For the purposes of brevity, this study will refer to enterprise and entrepreneurship education as 'entrepreneurial education' or EE. Entrepreneurial education as a term acknowledges both the similarities and the differences between enterprise and entrepreneurship education without substituting one term for the other.

Alongside the growth in EE programmes, there has been increased provision of extracurricular enterprise activities (Lilischkis et al., 2015). Extracurricular activities occur outside of scheduled teaching time and are distinct from in curricular activities due to their voluntary 
nature. Such activities, initiated by staff or students are often associated with a student's subject of study, and are employability focused, cultural or sport-based (Milner et al., 2016). Participation in extracurricular activities offers several student-learning benefits including enhancing confidence, building stronger social ties and interpersonal skills development (Bartkus et al., 2012; Milner et al., 2016). In the UK, with the introduction of the Higher Education Achievement Record (HEAR), a record of university students' extracurricular achievements, participation in such activities is now certificated. Although HEAR inclusion is voluntary, it signifies a drive towards quantifying participation in extracurricular activities and recognising their value to students' development and learning (Milner et al., 2016).

Extracurricular activities are perceived to complement in-curricular provision and studies note an increase in the provision of EE extracurricular activities (Lilischkis et al., 2015; Vanevenhoven and Drago, 2015). This includes activities such as business competitions, networking events, guest talks and student-led clubs (Rae et al., 2012; Vanevenhoven and Drago, 2015; Pittaway et al., 2015) and are distinctive from other extracurricular activities in aiming to develop students' entrepreneurial knowledge, skills and capabilities (Rae et al., 2012; Lilischkis et al., 2015). Prior studies have examined the benefits to participants of engaging in these activities including opportunities to experiment with entrepreneurial practice (Pittaway et al., 2011) and connect with peers (Cordea, 2014; Pittaway et al., 2015). However, the value extracurricular enterprise activities offer for enhancing entrepreneurial learning processes has not been explored within the literature (Watson et al., 2018).

Considering the importance of entrepreneurial learning to the entrepreneurial process, from nascent to established entrepreneur (Harrison and Leitch, 2005), it is critical to review the value of differing entrepreneurial learning platforms. Research into student's entrepreneurial learning enables us to identify earlier in the entrepreneurial process what enhances, and could subsequently accelerate, entrepreneurial learning. Further understanding of these processes is 
required, for example, understanding of the role platforms like extracurricular enterprise activities have upon students' entrepreneurial learning processes.

The rationale for conducting this study derives from the observation that although extracurricular enterprise activities have increased (Rae et al., 2012), as has the domain of entrepreneurial learning (Wang and Chugh, 2014), limited research examines links between the two phenomena. The existing EE literature largely explores what types of in-curricular activities are most effective in enhancing students' entrepreneurial awareness, capabilities and intentions (Rideout and Gray, 2013; Nabi et al., 2017). Literature evaluating extracurricular enterprise activities in enhancing students' learning capabilities remains nascent (PadillaAngulo, 2017), as is examining entrepreneurial learning from a student perspective (Pittaway and Cope, 2007a; Politis et al., 2010; Mueller and Anderson, 2014).

Hägg and Kurczewska (2018) noted students' entrepreneurial learning processes are often different from entrepreneurs. Therefore, it is important to understand how learning processes differ and the mechanisms that enhance them (Thrane et al., 2016). The existing literature on entrepreneurial learning for HE students concentrates on educator and stakeholder perspectives of how students learn (Hunter and Lean, 2018) or assumes entrepreneurial learning results from developing specific competencies (Morris et al., 2013) by imposing metrics of entrepreneurial learning that are designed to capture pre and post data. Indeed, few studies identify how entrepreneurial learning differs when enacted through other 'types' of learning platform such as extracurricular enterprise activities.

This study makes two key contributions for academic and practitioner communities. Firstly, it provides novel insights regarding how extracurricular enterprise activities enhance entrepreneurial learning through examining what activities students engage in and the perceived value they attain, thereby contributing understanding regarding the value of EE, the 
role of extracurricular enterprise activities and 'what works' (Lilischkis et al., 2015; Bonesso et al., 2018). Secondly, it challenges the dominance of in-curricular EE provision in promoting students entrepreneurial learning processes offering insights into the perceived value of engagement in extracurricular enterprise activities.

The results offer insights for enterprise educators in their design and delivery of extracurricular enterprise activities and wider EE activities. The study explores the following research questions:

1. What are student perceptions of entrepreneurial learning within their HE contexts?

2. What is the perceived value of extracurricular enterprise activities to participants?

3. How does engagement in extracurricular enterprise activities enhance entrepreneurial learning processes, particularly experiential, social and self-directed learning?

The following section provides an overview of the EE and entrepreneurial learning literature. The methodology is discussed and thereafter the data analysis and results outlined. The 'Discussion' and 'Conclusions' sections outline the contribution of the research, its limitations and future research opportunities.

\section{Literature Review}

Enterprise and Entrepreneurship Education

Although the UK QAA (2018) guidelines provide clarity, on the aims and objectives of EE, there remains contention on how 'best' to teach entrepreneurial concepts (Johannisson, 2016) with a diversity of pedagogical approaches employed by enterprise educators (Neck and Greene, 2011; Fayolle et al., 2016). Enterprise and entrepreneurship are difficult concepts to teach as the rigidity of an academic environment is perceived to conflict with the complexity and variability of the entrepreneurial process (Johannisson, 2016). Educators are constrained 
by institutional requirements yet need to employ innovative teaching methods (Pittaway and Edwards, 2012; Lackéus, 2014). EE provision is further criticised for lacking a multidisciplinary approach with Business Schools often dominating its development and delivery (Klapper and Refai, 2015; Preedy and Jones, 2015). Recently, there have been calls for a shared understanding among educators regarding how to teach EE (Fayolle, 2013; Jones, 2019).

Another challenge for EE is measurement of programme impact (Nabi et al., 2017; Jones et al., 2017). Martin et al., (2012), Rideout and Gray, (2013) and Nabi et al., (2017) reviews summarise the focus of existing EE outcomes as; EE's acceleration of business start-up, enhanced intentions to engage in entrepreneurship, development of entrepreneurial competencies/skills and impacts on entrepreneurial attitudes. However, measuring knowledge/skills improvements is challenging to attribute to specific interventions (Morris et $a l ., 2013)$. Studies measuring entrepreneurial intentions are challenged by seeking to account for exogenous factors influencing an individual's intentions (Krueger et al., 2000). Although the literature suggests a positive relationship between EE and enhanced entrepreneurial intention (Lorz et al., 2013; Vanevenhoven and Liguori, 2013) several studies suggest the opposite, that EE can reduce entrepreneurial intention among students (Oosterbeek et al., 2010; Joensuu et al., 2013).

EE programmes often fall into two types; theoretically oriented, whereby students learn about enterprise and practically oriented, whereby students learn for and through enterprise activity with a focus on experiential practice (Gibb, 2002; Pittaway and Edwards, 2012). It is accepted that enterprise educators need to base their teaching approaches on practice based and experiential learning models, with the educator as facilitator (Neck and Corbett, 2018). This latter 'type' of teaching approach emphasises andragogical and heutagogical approaches to 
teaching which enhances students' self-efficacy beliefs and entrepreneurial intention (Hägg and Kurczewska, 2016; Jones, 2016). Heutagogical approaches are becoming increasingly popular among enterprise educators (Neck and Corbett, 2018) with a focus on developing students' capability to learn effectively (Hase and Kenyon, 2000; Blaschke, 2012). This emphasis upon learner responsibility aligns with a guiding principle of EE, to develop students' autonomous and leadership behaviours (Bacigalupo et al., 2016). Those students who acquire the capability to learn effectively will potentially thrive in entrepreneurial environments, which are characterised by uncertainty and ambiguity (Neck and Corbett, 2018).

The EE curriculum is continually evolving and seeking the optimum methods to prepare students for graduate entrepreneurship (Neck et al., 2014). The need for experiential learning is a common theme within EE literature (Thrane et al., 2016), however what platforms enable experiential learning to occur remains under researched. It is proposed that the practical nature of extracurricular activities promotes the development of necessary competencies for engagement in entrepreneurial activities (Bonesso et al., 2018). However, extracurricular enterprise activities remain unresearched for the potential they offer for entrepreneurial learning.

\section{Extracurricular Enterprise Activity}

Extracurricular activities occur outside the scheduled timetable and are distinct from incurricular activities due to their voluntary nature. Such activities are initiated by either staff or students and may be associated with a student's study subject, employability focused or cultural or sport-based (Clegg et al., 2010; Milner et al., 2016). Extracurricular activities are perceived to enhance student's interpersonal and 'soft' skills (Milner et al., 2016). The more active an individual is with these activities, the greater the likelihood that they will develop their skills (Rubin et al., 2002). 
Extracurricular enterprise activities are distinctive in their focus upon developing students' entrepreneurial knowledge, skills and capabilities (Rae et al., 2012; Lilischkis et al., 2015). Activities include business competitions, networking events, business incubation services and raising awareness of entrepreneurship as a career option (Lilischkis et al., 2015; Vanevenhoven and Drago, 2015). Prior studies have focused upon mapping extracurricular enterprise activities at universities and gathering educator perspectives of benefits attained (Rae et al., 2012; Lilschkis et al., 2015; Vanevenhoven and Drago, 2015). Despite the growing popularity of these activities, limited research has been undertaken on the learning experiences of students engaging in business planning competitions (Watson et al., 2018). This study aims to move beyond mapping these activities to understand the perceived value of participation in extracurricular enterprise activities, and the perceived value to students' entrepreneurial learning processes. Due to the diversity of extracurricular activities which are available at HE institutions it is important to also recognise the contextual nature of the learning that results from participation.

\section{Entrepreneurial Learning}

Learning is considered an integral aspect of the entrepreneurship process from nascent to established entrepreneurs (Harrison and Leitch, 2005; Honig and Hopp, 2018) and research examining entrepreneurial learning has proliferated (Blenker et al., 2014). Existing literature attempts to homogenise entrepreneurs' learning but understanding different learning orientations and styles of individual entrepreneurs is important in appreciating how start-ups emerge (Honig and Hopp, 2018). For example, students' learning processes are considered different from practicing entrepreneurs (Mueller and Anderson, 2014; Hägg and Kurczewska, 2016) as a start-up within a university environment exposes individuals to differing pressures and resources (Shirokova et al., 2017). Thus, literature on practicing entrepreneurs cannot be easily translated within the HE context and a range of theoretical frameworks underpin EE 
design that draw from both educational and entrepreneurial disciplines (Rideout and Gray, 2013; Thrane et al., 2016). The EE discipline has grown more rapidly than our understanding of how to effectively teach it and the learning philosophies that underpin it (Fayolle, 2013; Neck and Corbett, 2018).

Traditionally, entrepreneurial learning has been viewed as an individual phenomenon concerned with "acquisition and development of the propensity, skills and abilities to found, to join or to grow a venture" (Hamilton, 2011, p. 9). Entrepreneurial learning is regarded as important for successful venture creation as it assists individuals with coping with uncertainty and ambiguity (Politis, 2005). However, entrepreneurial learning is also important for personal and social development of the entrepreneur (Rae, 2004) and entrepreneurial learning can also be regarded as a social phenomena dependent upon its context (Taylor and Thorpe, 2004; Mueller and Anderson, 2014).

\section{Experiential learning}

Experiential learning is a dominant perspective within the entrepreneurial learning literature due to the practical nature of entrepreneurship (Politis, 2005; Honig and Hopp, 2018) with growing importance of including experiential learning opportunities as a component of EE (Neck et al., 2014; Kuratko and Morris, 2017). Practical 'hands on' learning activities are regarded as effective in enhancing entrepreneurial knowledge, skills and capabilities (Neck and Greene, 2011; Rideout and Gray, 2013; Kassean et al., 2015). Typically, such activities include work based learning opportunities, consultancy projects, reflective portfolios and running a start-up as part of a module or programme (Pittaway and Cope, 2007a; Arranz et al., 2017). However, it is important to note that the extent to which experiential activities are transformed into knowledge will depend on an individuals' learning preferences (Honig and Hopp, 2018) 
and their readiness to learn. It is also important for experiential knowledge to be connected to students' prior knowledge, experience and beliefs (Thrane et al., 2016). As each student is different, the educator's role enables learners to pursue a personalized entrepreneurial learning process (Thrane et al., 2016). This is challenging, both Neergard et al., (2012) and Nabi et al., (2016) argue that entrepreneurial learning may be difficult to achieve through in-curricular activities alone. This raises the question of whether extracurricular activities are the most effective platform for personalized learning considering the autonomy students enjoy in their selection and pursuit of such activities.

\section{Social learning}

Social learning models are influential, grounded in social constructionist perspectives emphasising how relationships influence entrepreneurial activities whereby entrepreneurs learn from peers and role models (Taylor and Thorpe, 2004; Hamilton, 2011). Entrepreneurial learning is not always active and can be achieved through observation (Cope, 2005) therefore entrepreneurial guest speakers are a common pedagogical approach in assisting students to envisage entrepreneurial life. Studies found the more exposure students have to entrepreneurial guest speakers the increased impact on self-efficacy and motivations towards entrepreneurship (Zozimo et al., 2017). Toutain et al., (2017) call for further research into entrepreneurial learning within groups and through cooperation, in particular how individual learning evolves due to the social environment. This study was cognisant of this literature gap and addresses it through the examination of entrepreneurial learning in group based extracurricular activities such as clubs/societies.

As entrepreneurs collaborate to form learning networks and communities (Greve and Salaff, 2003; Cope et al., 2007), they are an important facet of an individual's social capital. The development of networks is important in supporting nascent entrepreneurs with start-up 
(Davidsson and Honig, 2003). Social networks provide an opportunity for entrepreneurs to make sense of their ideas (Shirokova et al., 2017) and the influence social networks have upon an entrepreneur's learning journey will differ according to learning style (Honig and Hopp, 2018). The recognition of the role social networks can have in enhancing entrepreneurial outcomes, through social and personal emergence (Rae, 2004), has led to a rise in 'team entrepreneurship' delivery models of EE whereby students work in groups through the stages of running a business (Butler and Williams-Middleton, 2014).

\section{Self-Directed Learning}

Self-directed learning is about creating an educational environment whereby students can discover their own strategies for learning with educators acting as facilitators (Hase and Kenyon, 2000; Bhoyrub et al., 2010). As the emphasis is upon creating autonomous learners, educators provide guidance through suggesting resources, setting assessment criteria, and encouraging students to self-determine their learning often through independent reading and online materials (Brockett and Hiemstra, 1991). However, self-directed learning is not an isolated pursuit of knowledge as learning often occurs within a social context, in peer groups and with mentors who enhance learning outcomes (Garrison, 1997).

Active learning is an important component of self-directed learning approaches and links with experiential learning models where action and reflection on action is emphasised (Kolb, 1984). Grow's (1991) model of self-directed learning argues there are four key stages whereby the tutor moves from 'authority' and the student 'dependent' in Stage One to tutor as 'consultant' and student as 'self-directed' by Stage Four. Neck and Corbett (2018) apply this model to EE, offering examples of students undertaking start-up or engaging in consulting activity as a typical Stage Four activity. 
The part self-directed learning has to play in enhancing HE student's entrepreneurial learning experiences has not been researched. Prior studies that begin to link the two learning concepts such as Tseng's (2013) exploration of the conceptual relationship between self-directed learning and entrepreneurial performance, and Van Gelderen's (2010) study recommending the capacity for autonomous action be developed through self-directed learning, lay the foundations for this research which specifically examines how engagement in self-directed learning opportunities such as extracurricular activities may enhance entrepreneurial learning processes.

\section{Summary}

Although, these learning models provide a framework for examining entrepreneurial learning, it is noteworthy that there are numerous factors in the learning process. Individuals' prior entrepreneurial experiences, influence of role models and professional work experience potentially act as facilitators to the entrepreneurial process (Krueger, 1993; Shirokova et al., 2017; Zapkau et al., 2017). As such, each individuals' learning experience is unique. The key models within the entrepreneurial learning literature are those of experiential, social and selfdirected learning. This study explores whether engagement in extracurricular activities by students enables learning of these key types and thereby enhances entrepreneurial learning. The following conceptual framework indicates the key areas of exploration and the theoretical framing. 


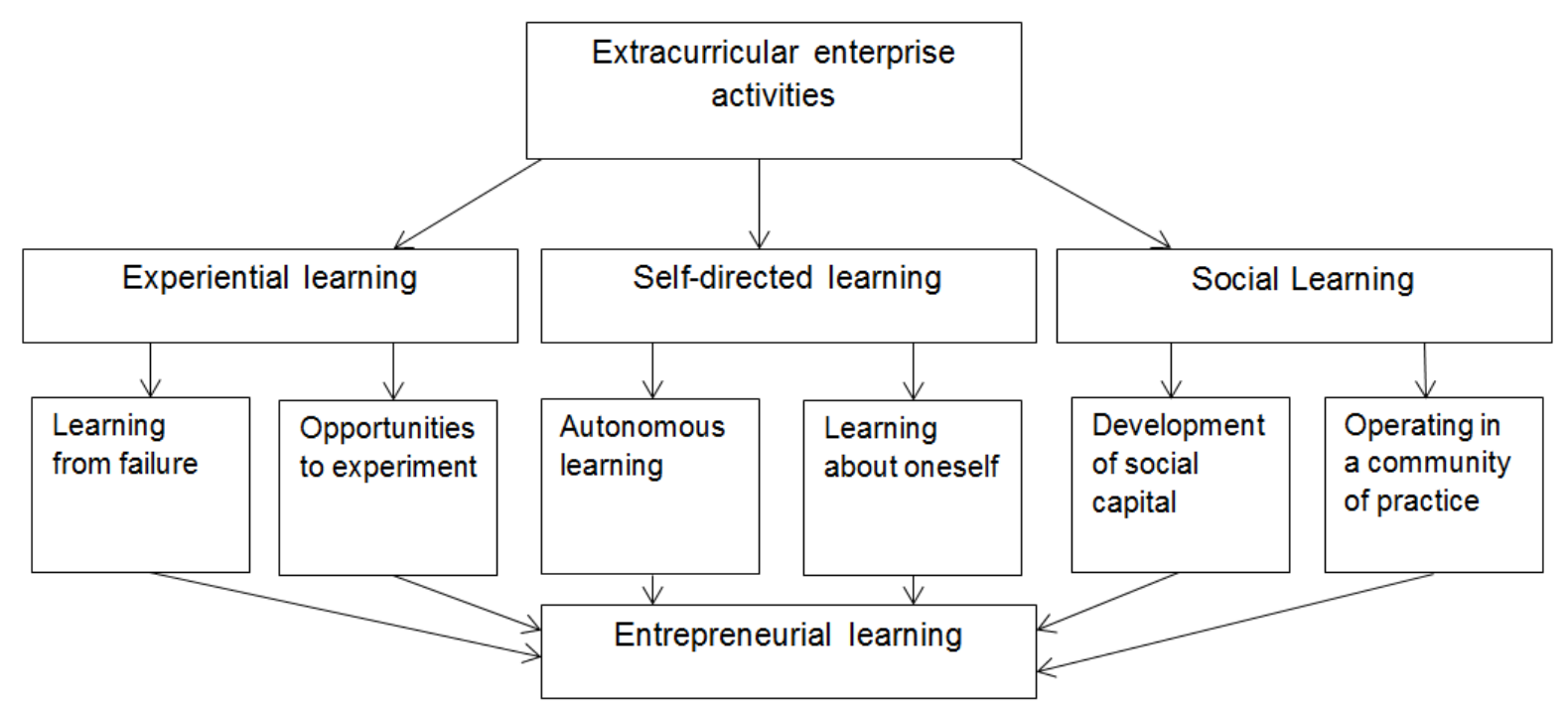

Figure 1. Conceptual Framework of entrepreneurial learning and extracurricular enterprise activities

\section{Methodology}

This study draws on semi-structured survey and interview data from 81 participants across 24 UK universities. All participants were engaged in extracurricular enterprise education activities (students) or designed/delivered these activities (educators). This was not a historical review or a predicted forecast but a gathering of data as learning was evolving and emerging. The aim was to explore, rather than to quantify and predict, thereby an inductive methodological approach was adopted to explore emergent themes using qualitative methods to gather rich descriptive data (Saldana, 2013).

A UK sample was selected as prior studies highlight how different cultural contexts hinder comparability of findings within EE research (Bae et al., 2014). The sample drew from 24 universities from across the UK of varying size and date of establishment. As the population of the UK is heavily weighted towards English counties (ONS, 2017), the sample was weighted towards English universities. Despite the narrowing of the sample's geography to the UK, it 
is recognised that the sample is not culturally homogenous as each university has their own cultural norms, identity and operational context (Lilschkis et al., 2015).

A semi-structured survey of $55 \mathrm{HE}$ students and in-depth interviews with $23 \mathrm{HE}$ students and three enterprise educators was undertaken. Purposive sampling was employed for the surveys and interviews with students to identify information rich cases based on the following criteria (Patton, 1990); a) a student or educator engaged in extracurricular enterprise activities b) for at least six months c) at a UK university. The survey $(n=55)$ and student interviews $(n=23)$ both contained questions regarding participants' perceptions of the perceived value of participating in extracurricular enterprise activities. Each interview began by inviting participants to share their entrepreneurial experiences with EE. This open element of the interview was designed to enable participants the opportunity to raise topics of interest to them and identify further areas of enquiry (Booth et al., 2009). The interviews were designed to unpick topics raised from the survey findings thereby giving participants the opportunity to discuss their experiences in detail and provide rich contextual data. All participants were also asked core questions for comparability purposes (Strauss and Corbin, 1998), which were related to the research questions. A further three enterprise educators were interviewed and this aided the researcher in understanding aspects of extracurricular enterprise activities that student participants were not privy to, such as design of activities and/or the funding and organisational challenges continuation of activities faced.

Data collection and analysis were considered an on-going and iterative process whereby data analysis begun as soon as data collection commenced with emergent themes noted alongside field notes (Booth et al., 2009). Codes noted during interviews were transferred into an initial coding list which was added to and refined during transcription. Discourse was an important aspect given its ability to inform researchers and participants' perspectives of the phenomena 
under investigation, as such interview data was approached from a Foucauldian perspective (Foucault, 1970).

Manual coding consisted of formulation of a coding table to plot trends such as areas of learning development and the perceived value of engagement. The coded table was added to and refined after each transcription providing a visual representation of emergent themes and enabling repeat occurrences to become apparent (Strauss and Corbin, 1998). The same data was inputted and coded using NVIVO with each transcript coded line by line. This technique forces the researcher to focus upon the words spoken without considering context and can mitigate against preconceptions (Ritchie et al., 2013). The NVIVO codes were compared with the manual coding table to evaluate if further nuances were identifiable. Any modifications made to the manual coding list, as a result of coding through NVIVO, were recorded in an analytic memo to track its evolution. This enabled constant review of the analytic process, developed and linked concepts into groups, and assisted in the development of core codes (Strauss and Corbin, 1998). The findings of the analysis are presented in the following section.

\section{Analysis and Results}

This section outlines the types of extracurricular enterprise activities participants engaged in, the benefits of engagement and the perceived value these activities had for enhancing elements of entrepreneurial learning such as experiential, social and self-directed learning processes.

\section{Types of extracurricular enterprise activities}

Contextual information was collected from student participants to establish the types of extracurricular enterprise activities participants engaged in. Participants were involved in multiple activities; the average being 2.6 (see Table 1). Networking events were the most popular activity, followed by socialising and guest speaker events. Mentoring and coaching 
activities and business competitions were less popular but emergent themes. 'Other' classifies those activities participants were unsure had a clear label, this included participation in student led enterprise groups.

\section{[Table 1 here]}

\section{Perceived value of engaging in extracurricular enterprise activities}

Student participants were questioned regarding the value derived from participation, emergent themes were; skills development, knowledge acquisition, personal growth, social capital development, venture creation/growth and enhanced employability. Figure 2 outlines the themes and percentages of the sample citing such perceived value.
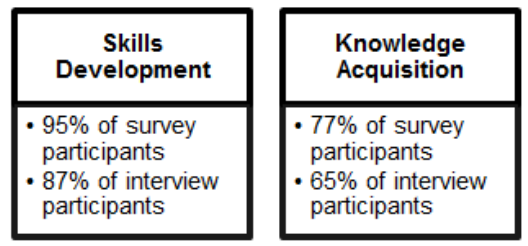

\begin{tabular}{|l|}
\hline Personal Growth \\
\hline - $90 \%$ of survey \\
participants \\
- $43 \%$ of interview \\
participants \\
\hline
\end{tabular}

\begin{tabular}{|l|}
\hline $\begin{array}{c}\text { Development of } \\
\text { Social Capital }\end{array}$ \\
\hline - $74 \%$ of survey \\
participants \\
- $70 \%$ of interview \\
participants \\
\hline
\end{tabular}
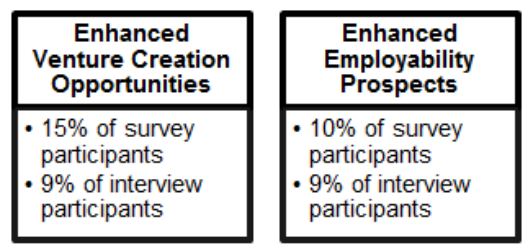

Figure 2. Perceived value to individuals engaged in extracurricular enterprise activities

Figure 2 illustrates that skills development was the most valuable benefit of participating in extracurricular enterprise activities, $87 \%$ of interview participants and $95 \%$ of survey participants valued the skills developed for their applicability to both entrepreneurial activity and employment preparedness. Participants tended to be 'outcome' rather than 'process' focused discussing the value of activities in relation to their future plans. Participants associated their acquisition of knowledge, skills and capabilities with their preparedness for a life beyond university whether as an entrepreneur or employee. They acknowledged that the knowledge, skills and experiences afforded by participating in extracurricular enterprise activities enhanced their abilities to pursue future entrepreneurial endeavours. Engagement in 
extracurricular enterprise activities was considered to prepare them for business ownership or furthering existing endeavours:

'The activities I have participated in have provided me with key information and further experience that will be instrumental in my future business endeavours' (Respondent S)

Engagement in extracurricular enterprise activities was regarded as valuable for enhancing employability prospects. Participation was a positive addition for Resumes and perceived to increase graduate employment opportunities with a perception that employers favoured graduates who participated in extracurricular enterprise activities:

'It shows employers that you have taken a keen interest in furthering your enterprise skills' (Survey participant).

Upon cross-referencing the types of extracurricular enterprise activities participants engaged in and the benefits cited from engagement, patterns emerged. Participation in networking and guest speaker events were activities perceived to be most likely to achieve benefits, in particular skills development, personal growth and knowledge acquisition alongside enhancement of social capital. Socialising activities were perceived as beneficial in developing skills and knowledge, assisting in personal growth and developing social capital. Mentoring activities, competitions and trading practice were perceived to enhance participants' skills, knowledge and personal growth but to a lesser extent than other activities.

Perceived value of engagement for enhancing experiential learning processes

Participants identified having more varied learning experiences from engaging in extracurricular enterprise activities than they would have experienced during in curricular activities due to their diverse and practical nature. Experiential learning opportunities, such as 
competitions, enabled participants to develop technical skills such as pitch practice, networking and selling of goods/services.

'You get to learn skills that you wouldn't anywhere else in the university, especially networking skills' (Respondent D).

These findings echo Watson et al., (2018) and Bell and Bell (2016) who examined businessplanning competitions and found development of networking skills and self-confidence were particularly valuable aspects of student participation. The experiential nature of the activity allowed development of specific competencies although Watson et al., (2018) critique application of these competencies for future entrepreneurial endeavours, suggesting competencies developed during competitions are useful for preparing for future competitions, 'competition competency', rather than start-up. Instead business competitions should focus on learning through action rather than static business planning for future endeavours (Watson and McGowan, 2019).

Participants emphasised the experiential nature of extracurricular enterprise activities, 'doing' and 'putting into practice', as crucial for enhancing entrepreneurial learning. They described entrepreneurial learning as "hands on" and "practical" making it distinct from generally learning about business. The limitations of in-curricular activities, which were perceived to be "too theoretical", led them to try extracurricular opportunities as a means to "experiment", "practice dealing with uncertainty" and learn "different approaches".

"University is about talking about stuff and writing about what you will do ... but this [participation in extracurricular activities] is a practical way of doing things" (Respondent F)

“There's a lot of practicality whereas on your course it's pretty much about theory. There's only a certain amount you can learn from theory, whereas the stuff in the workshops you can apply" (Respondent E) 
The ability to cope with risk of failure is considered an important component of entrepreneurial learning yet failure can be difficult to simulate in an educational environment as curricula is focused upon awarding achievement (Pittaway and Cope, 2007b). Participants discussed this difficulty describing their engagement in extracurricular enterprise activities as an alternative process to learn and experiment with failure:

"It's all very well a lecturer telling us all this, you know the textbook says, but it's another thing to say look this is what really happened with this person in real life and they lost this amount of money, you know they lost 50 grand, or they made 50 grand, whatever the case may be" (Respondent P)

The ability to cope with risk of failure is considered an important component of entrepreneurial learning (Politis, 2005) and participants noted a limitation to in-curricular activities were inadequate opportunities to practice coping with uncertainty and failure. Instead, extracurricular enterprise activities were perceived to be represent 'real life' and a realistic platform for practicing entrepreneurial activity.

Table 2 lists the stages of the experiential learning process (Kolb, 1984) and categorizes which were emergent in the analysis.

\section{[Table 2 here]}

Although extracurricular activities provided an opportunity to acquire practical experience and were a platform to actively experiment, what appeared to be missing were structured opportunities for reflection and subsequent abstract conceptualisation processes. Reflection upon learning, appeared challenging for participants. There were instances of hesitation with several participants stating they were unsure how to discuss reflection. This was surprising considering reflection upon learning is a major component of in-curricular assessments on EE programmes (Neck and Greene, 2011). It seemed EE experiences had not offered adequate 
opportunities for participants to reflect upon their learning and thereby complete all stages of the experiential learning cycle.

However, there was evidence of reflection by participants on their understanding of 'enterprise' which resulted from engagement in extracurricular enterprise activities. Individuals discussed widening their understanding of the concept of enterprise through participation:

'Entrepreneurship is greater than business knowledge, it's everything involved in that mentality, that thinking from the ideology, to your ethos, to your objectives. It's about how business runs, your ethos, how you treat people' (Respondent $\mathrm{H}$ )

This participant's understanding of enterprise evolved beyond 'business knowledge' to recognition of one's personal philosophy and how interaction with others affected entrepreneurial endeavours. Their enhanced appreciation of enterprise and its contextual application occurred as a result of participation in extracurricular enterprise activities.

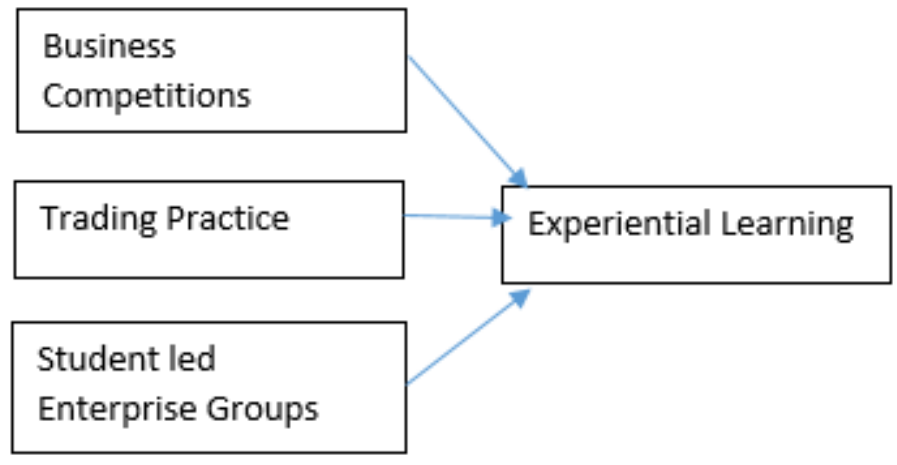

Figure 3 - Types of Extracurricular Enterprise Activity that enhance experiential learning processes

Perceived value of engagement for enhancing social learning processes

Although extracurricular activities varied in content and delivery there was a common perception from students, regardless of circumstances, that they were part of a learning community. Prior studies highlighted how individuals within community settings, such as 
sports teams find their learning enhanced by interacting with others with a shared purpose (Lave and Wenger, 1991).

Participants described opportunities for social learning afforded by engagement in extracurricular enterprise activities; $70 \%$ of interviewees and $74 \%$ of survey participants perceived learning to be in conjunction with others and enhanced by interactions within a likeminded community. Extracurricular enterprise activities were perceived to unite likeminded students with common goals to support and nurture collective entrepreneurial development. This is important for learning processes as individuals may socially share knowledge before reflecting and processing it themselves (Vygotsky, 1978).

Participants noted acquiring entrepreneurial knowledge when interacting with peers and guest speakers. The social nature of extracurricular enterprise activities enabled signposting to resources and knowledge gain from listening to and interacting with entrepreneurial others. Participants described how engagement in extracurricular enterprise activities meant they were effectively informed regarding available entrepreneurial resources and support. They described extracurricular enterprise activities as an entry point into wider university support and providing information for enterprise schemes they could participate in to benefit their business ideas.

Alongside the establishment of professional contacts, extracurricular enterprise activities gave participants opportunities to socialise and build friendships. Participants described becoming part of a like-minded community which entrepreneurially inspired and motivated them. This echoes Mueller and Anderson (2014) who note students feel a sense of responsibility for the learning processes of their peers. Enterprise and Entrepreneurship Educators noted the benefits witnessed in extracurricular enterprise activities in bringing students with similar mind sets together, highlighting the emergence of entrepreneurial communities. Participants believed and 
were considered by others, as operating in a community of practice. Communities of practice are places where individuals share and develop knowledge and understanding (Lave and Wenger, 1991). Hamilton (2011) noted this as a conducive setting for entrepreneurial learning processes.

Extracurricular enterprise activities where students engaged with entrepreneurs during networking and guest speaker events, were activities perceived to derive the most value for participants. Networking benefited participants through peer-to-peer learning, gaining a range of perspectives and stimulating thought processes. Survey participants (36\%) described enhancement of their networking skills as a benefit of participation.

Survey participants (74\%) and interviewees (70\%), discussed growth in the quantity and quality of their networks due to engaging in extracurricular enterprise activities. Participants described homogeneity of peers on their degrees as restricting their networks and saw extracurricular enterprise activities as a mechanism to engage with a wider group with a shared interest in enterprise and entrepreneurship:

\section{'You get the chance to meet other students of similar mind-set across different disciplines, especially as a business student, you may have an idea that ranges across different disciplines and it can be quite hard to meet such people' (Respondent E)}

The positioning of extracurricular activities outside of a specific faculty meant participants were likely to network and socialise with students from alternate disciplines. Some extracurricular enterprise activities involved the creation of inter-disciplinary networks bound by a shared interest in entrepreneurship and utilised to find information, seek advice/mentors and collaborate on ideas. Participants stated entrepreneurial thought processes were stimulated during such events, in a manner not possible in the curriculum, as they could interact with diverse individuals: 
'It's almost learning how different minds think to benefit your own thought process. Everyone thinks differently, it makes you reflect and learn. We make each other better' (Respondent I)

However, not all participants provided descriptions of enhanced social capital and it is important to recognise how demographic factors may enhance or limit an individual's propensity and ability to grow social capital (Greve and Salaff 2003). The study noted a male dominance throughout the coded theme of social capital. Discussion of peers, mentors and role models either known to the participant through EE initiatives, or admired from afar, were more likely to be male. Over half of participants discussed the influence of role models who were male family members, business mentors, friends and celebrity entrepreneurs. Only two women were mentioned as role models and this derived from two female respondents discussing their mothers. No female role models were mentioned in relation to engagement in extracurricular enterprise activities. This concurs with Jones (2014) and Shinnar et al., (2018) who posit historical masculinisation of entrepreneurship has informed UK HE approaches to EE and dissuaded female participation in EE initiatives.

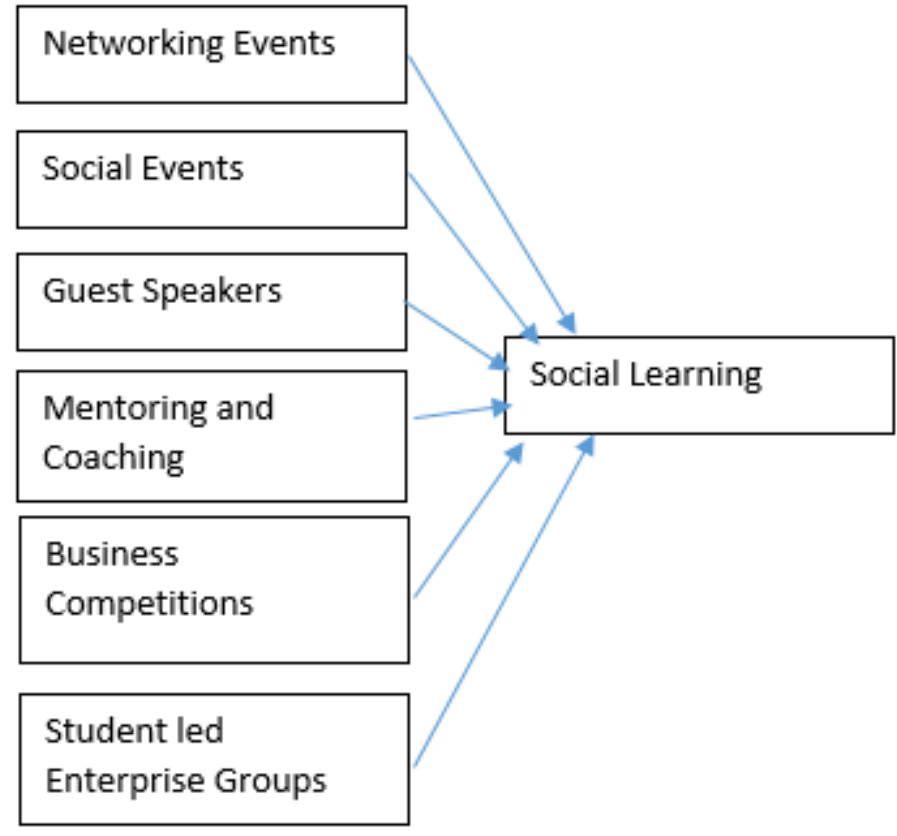

Figure 4 - Types of Extracurricular Enterprise Activity that enhance social learning processes 
Participants were self-motivated to learn about entrepreneurship seeking out activities both within and outside of the university to enhance their learning. This took the form of selfdirected learning activities, both individual, such as engaging in online forums, and collective such as student led enterprise groups. Recent developments in technology and global access to online resources appear to have assisted students' ability to self-direct aspects of their entrepreneurial learning. Participants used multiple online sources including Twitter, LinkedIn and Forbes to acquire information regarding entrepreneurship and shared information to an external audience through social media platforms. Participants valued the self-directed nature of engaging in activities as it provided autonomy to tailor their learning experience, engaging in targeted activities at a time convenient to them:

"I watch a lot of online videos on entrepreneurship. They allow an insight from people who have experience in areas that can't be conveyed in a classroom" (Respondent P)

"I read books on entrepreneurial leadership. Online videos are a great source of information. Many speakers are almost impossible to hear live, and listening to talks such as TED online allows you to see what a particular person of interest is doing and find the distinguishing characteristics that make them world class in their craft" (Respondent C)

The excerpts exemplify the routes students took to develop entrepreneurial learning as a result of independent searches and additional to staff-initiated activity. Participants were pursuing 'real life materials' in order to identify entrepreneurs they related to and then applying their learning from these sources to assess what they can personally improve upon. The informal nature of extracurricular activities was considered appealing when contrasted with the formal curriculum. Participants described positives to developing entrepreneurial knowledge, skills and experience within a non-assessed environment. The removal of academic pressure allowed 
participants to experiment with ideas in ways they did not feel possible on their degree programmes.

The self-directed nature of engaging in extracurricular enterprise activities enhanced participant's understanding of their own strengths and weaknesses with $90 \%$ of survey participants identifying personal growth as a benefit of participation and $43 \%$ of interviewees. Participants described feeling more able to self-reflect regarding their strengths and weaknesses and developing their 'person-ness' in ways the curriculum could not:

'[on a degree programme] you learn business acumen but do you learn about yourself? At uni people forget about that, they think you go to uni and you get a job. I think that's what universities have lost .... you should be finding yourself' (Respondent P)

Moreover, respondents described how participation in extracurricular enterprise activities had furthered personal growth in terms of diversifying life experiences, enhancing self-awareness and instilling confidence. Whether this benefited entrepreneurial endeavours was a consideration for participants, but personal growth opportunities were also valued individually on merit. Participants described an increase in self-confidence and self-efficacy bolstered by the experiences afforded by engagement in extracurricular enterprise activities and knowledge that they were able to identify and shape their involvement in such activities. This offered belief that they were effectively prepared for future entrepreneurial activities.

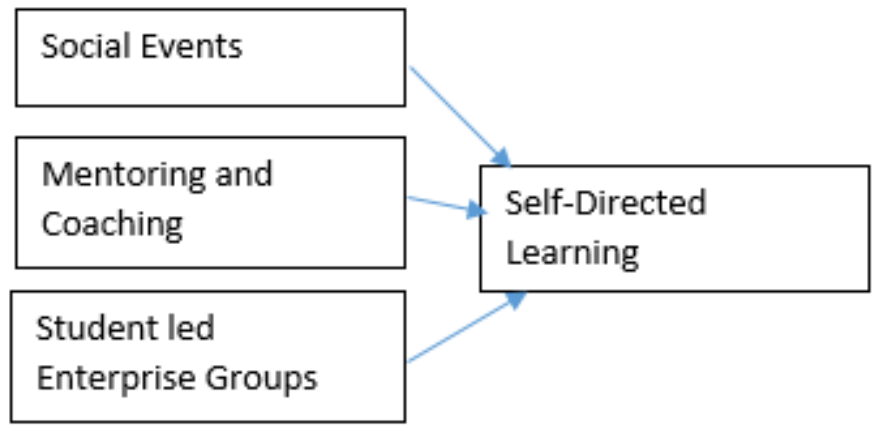

Figure 5 - Types of Extracurricular Enterprise Activity that enhance self-directed learning processes 


\section{Discussion}

This study highlights the benefits of participation in extracurricular enterprise activities and particularly, the perceived value that engagement offers for enhancing entrepreneurial learning processes. Some benefits were generalised in a wider context of learning while others were specific to the key components of entrepreneurial learning; experiential, social and selfdirected learning. Due to the practical nature of entrepreneurship, experiential learning opportunities are regarded as particularly valuable for enabling entrepreneurial learning processes (Neck et al., 2014; Honig and Hopp, 2018). The need for experiential learning is a common theme within EE literature (Thrane et al., 2016) although what platforms enable experiential learning remains under researched. Participants identified extracurricular enterprise activities as a possible alternative platform. The physical 'doing' and applying extracurricular enterprise activities allowed participants to learn entrepreneurially and supplemented in-curricular activities that were considered as overly theoretical.

Undertaking extracurricular enterprise activities enabled participants to be part of a community of entrepreneurial practice. Learning was regarded in conjunction with, and enhanced by, entrepreneurial others and participants used activities to establish personal and professional contacts. This supports Hunter and Lean (2018) whom emphasised the importance of support from peers for creating an appropriate entrepreneurial learning environment.

It was important for participants to establish contacts outside their degree programmes that they felt shared a similar entrepreneurial mind set. Networks are a facet of an individual's social capital (Greve and Salaff, 2003) and development of networks has been found to support nascent entrepreneurs with start-up (Davidsson and Honig 2003; Shirokova et al., 2017). However, male role models appeared to dominate, which does not reflect the spectrum of entrepreneurship. While this was not highlighted as an issue by participants this has 
implications for enterprise educators and student organisers of EE activity when designing and delivering EE initiatives.

The development of students' autonomous and self-leadership behaviours is a principle of EE (Bacigalupo et al., 2016; QAA 2018) and self-direction is an important facet of effective entrepreneurial learning (Van Gelderen, 2010; Jones, 2019). Both physical (student led enterprise groups) and virtual (online forums) avenues were utilised by participants to selfdirect aspects of their learning. Participants sought materials they felt were relevant to their specific circumstances and aspirations. Leading their learning and tailoring to their needs was empowering and enabled personal growth and self-reported enhanced self-efficacy.

An emergent theme was the motivations for engaging in extracurricular enterprise activities and the dominant reason was perceived limitations of in-curricular activities for genuine entrepreneurial learning. Participants described the following perceived limitations of incurricular enterprise education; limited opportunities for experimentation and practicality, ineffective simulation of real life risk and failure, and a formality that does not reflect the informal nature of entrepreneurial action. Although participants recognised practical learning opportunities were often made available during in-curricular sessions, it was the nature of extracurricular enterprise activities where you are "pushed in at the deep end", and were able to tailor what activities you engage in and with whom you engaged with, which was considered valuable in enhancing entrepreneurial learning processes.

Engagement in extracurricular enterprise activities was therefore not just an add-on to in class learning but considered an essential means to experience a diverse range of activities and assist participants in developing their entrepreneurial capabilities. In-curricular content was 
perceived to be overly theoretical and structured whereas extracurricular activities were practical and allowed for experimentation. One participant stated - "you need to do entrepreneurship to be good at it" (Respondent F).

However, extracurricular enterprise activities have their own limitations particularly in their restricted ability to encourage reflective activity. Jones (2019) states the aim of EE should be the development of increased capacity for self-negotiated action and that self-directed learning approaches needs to be embedded into EE and underpinned by repeated reflection (Jones, 2019). It is the repeated reflection element that appears to be missing from extracurricular enterprise activities as it depends on participant motivation to engage in, and understanding of, reflection processes and whether these activities actively encourage and support reflective processes. In particular, extracurricular activities would benefit from additional built in reflection activities to assist participants in completing the experiential learning cycle. A suggested area for future research is to explore how extra-curricular activities can be developed to encourage participants to successfully accomplish each stage of the experiential learning cycle.

The number of participants who directly linked participated in extracurricular enterprise activities to then starting up a business was unexpectedly low. This may be due to the fact many participants did not see themselves starting a business immediately upon graduation as they wished to gain industry experience first and entrepreneurial learning was also seen as much broader than just leading to business start-up.

\section{Conclusions}

This study illustrates extracurricular enterprise activities have value for the benefits they bring to HE students' entrepreneurial learning processes and offer an alternative learning platform to 
in-curricular activities. However, extracurricular activities are not without their limitations as a learning platform as they lack opportunities for deep reflection and do not necessarily mirror the diversity of the entrepreneurial world.

This research is important in providing empirical evidence of the perceived value engagement in extracurricular enterprise activities has for entrepreneurial learning processes. However, findings are not generalised to the HE population and instead explore extracurricular enterprise activities within a UK context. Further examination of these activities through comparative analysis across multiple countries is necessary for a deeper understanding of the value and potential of extracurricular activities.

\section{References}

Arranz, N., Ubierna, F., Arroyabe, M.F., Perez, C. and De Arroyabe, J.C. (2017), "The Effect of Curricular and Extracurricular Activities on University Students' Entrepreneurial Intention and Competences", Studies in Higher Education, Vol. 42 No. 11, pp. 1979-2008.

Bacigalupo, M., Kampylis, P., Punie, Y. and Van den Brande, G. (2016), "EntreComp: The Entrepreneurship Competence Framework". Publication Office of the European Union; Luxembourg, EUR

http://publications.jrc.ec.europa.eu/repository/bitstream/JRC101581/lfna27939enn.pdf

Bae, T.J., Qian, S., Miao, C. and Fiet, J.O. (2014), "The relationship between entrepreneurship education and entrepreneurial intentions: A meta-analytic review", Entrepreneurship: Theory \& Practice, Vol. 38 No. 2, pp. 217-254.

Barnard, A., Pittz, T. and Vanevenhoven, J. (2018), "Entrepreneurship Education in U.S. community colleges: a review and analysis", Journal of Small Business and Enterprise Development, Vol. 26 No. 2, pp. 190-208.

Bartkus, K.R., Nemelka, B., Nemelka, M. and Gardner, P. (2012), "Clarifying the Meaning of Extracurricular Activity: A Literature Review of Definitions", American Journal of Business Education, Vol. 5 No. 6, pp. 693-704.

Bell, R. and Bell, H. (2016), "An enterprise opportunity for entrepreneurial students: Student enterprise development and experience assessed through the student voice", Education + Training, Vol. 58 No. 7/8, pp. 751-765.

Bhoyrub, J., Hurley, J., Neilson, G.R., Ramsay, M. and Smith, M. (2010), "Heutagogy: An alternative practice based learning approach", Nurse Education in Practice, Vol. 10 No. 6, pp. 322-326.

Blaschke, L.M. (2012), "Heutagogy and lifelong learning: A review of heutagogical practice and self-determined learning", The International Review of Research in Open and Distributed Learning, Vol. 13 No. 1, pp. 56-71. 
Blenker, P., Trolle, S., Signe, E., Frederiksen, H., Korsgaard, S. and Wagner, K. (2014), Methods in Entrepreneurship Education Research: a Review and Integrative Framework, Education + Training, Vol. 56 No. 8/9, pp. 697-715.

Bonesso, S., Gerli, F., Pizzi, C. and Cortellazzo, L. (2018), "Students' Entrepreneurial Intentions: The Role of Prior Learning Experiences and Emotional, Social, and Cognitive Competencies", Journal of Small Business Management, Vol. 56 No. 1, pp. 215-242.

Booth, A, McLean, M. and Walker, M. (2009), Self, Others and Society: A Case Study of University Integrative Learning, Studies in Higher Education, Vol. 34 No. 8, pp. 929-939.

Brockett, R.G. and Hiemstra, R. (1991), Self-direction in adult learning: Perspectives on theory, research, and practice. Routledge: London.

Butler, C., and Williams-Middleton, K. (2014), "Team Conflict Contributing to Entrepreneurial Learning: Understanding Conflict as Positive within an Effectual Problem Space", International Journal of Entrepreneurship and Innovation Management, Vol. 18 No. 1 , pp. 5-22.

Clegg, S., Stevenson, J. and Willott, J. (2010), "Staff conceptions of curricular and extracurricular activities in higher education", Higher Education, Vol. 59 No. 5, pp. 615-626. Cope, J. (2005), "Toward a dynamic learning perspective of entrepreneurship", Entrepreneurship: Theory \& Practice, Vol. 29 No. 4, pp. 373-397.

Cope, J., Jack, S. and Rose, M.B. (2007), "Social Capital and Entrepreneurship: An Introduction”, International Small Business Journal, Vol. 25 No. 3, pp. 213-219.

Cordea, C. (2014), "The role of extracurricular activities and their impact on learning process", Annals of Faculty of Economics, Vol. 1 No. 1, pp. 1143-1148.

Davidsson, P. and Honig, B. (2003), "The role of social and human capital among nascent entrepreneurs", Journal of Business Venturing, Vol. 18 No. 3, pp. 301-331.

Fayolle, A. (2013), "Personal views on the future of entrepreneurship education", Entrepreneurship \& Regional Development, Vol. 25, pp. 692-701.

Fayolle, A, H. Landström, W.B. Gartner, and K. Berglund (2016), "The Institutionalization of Entrepreneurship: Questioning the Status Quo and Re-gaining Hope for Entrepreneurship Research", Entrepreneurship \& Regional Development, Vol. 28 No. 7/8, pp. 477-486.

Foucault, M. (1970), The Order of Things. Vintage: New York.

Garrison, D.R. (1997), "Self-directed learning: Toward a comprehensive model", Adult Education Quarterly, Vol. 48 No. 1, pp. 18-29.

Gibb, A.A. (2002). In pursuit of a new 'enterprise' and 'entrepreneurship' paradigm for learning: creative destruction, new values, new ways of doing things and new combinations of knowledge, International Journal of Management Reviews Vol. 4 No. 3, pp. 233-269.

Greve, A. and Salaff, J.W. (2003), "Social Networks and Entrepreneurship", Entrepreneurship: Theory \& Practice, Vol. 28 No. 1, pp. 1-22.

Grow, G.O. (1991), "Teaching learners to be self-directed", Adult Education Quarterly, Vol. 41, No. 3, pp. 125-149.

Hägg, G. and Kurczewska, A. (2016), "Connecting the dots: A discussion on key concepts in contemporary entrepreneurship education”, Education + Training, Vol. 58 No. 7/8, pp. 700714.

Hägg, G. and Kurczewska, A. (2018), "Who is the Student Entrepreneur? Understanding the Emergent Adult through the Pedagogy and Andragogy Interplay", Journal of Small Business Management, Vol. 57 No. 1, pp. 130-147.

Hamilton, E. (2011), "Entrepreneurial learning in family business", Journal of Small Business and Enterprise Development, Vol. 18 No. 1, pp. 8-26.

Harrison, R.T. and Leitch, C.M. (2005), "Entrepreneurial learning: Researching the Interface between Learning and the Entrepreneurial Context", Entrepreneurship: Theory \& Practice, Vol. 29 No. 4, pp. 351-371. 
Hase, S. and Kenyon, C. (2000) From Andragogy to Heutagogy, [online] Ulti-BASE In-Site http://pandora.nla.gov.au/nph-

wb/20010220130000/http://ultibase.rmit.edu.au/New/newdec00.html.

Honig, B. and Hopp, C. (2018), "Learning orientations and learning dynamics: Understanding heterogeneous approaches and comparative success in nascent entrepreneurship", Journal of Business Research, Vol. 94, pp. 28-41.

Hunter, L. and Lean, J. (2018), "Entrepreneurial learning - a social context perspective: evidence from Kenya and Tanzania", Journal of Small Business and Enterprise Development, Vol. 25 No. 4, pp. 609-627.

Joensuu, S., Viljamaa, A., Varamaki, E. and Tornikoski, E. (2013), "Development of Entrepreneurial Intention in Higher Education and the Effect of Gender: A Latent Growth Curve Analysis", Education \& Training, Vol. 55 No. 8/9, pp. 781-803.

Johannisson, B. (2016), "Limits to and prospects of entrepreneurship education in the academic context", Entrepreneurship and Regional Development, Vol. 28 No. 5/6, pp. 403-423.

Jones, C. (2016), "Enterprise Education: Towards the Development of the Heutagogical Learner", The All Ireland Journal of Teaching and Learning in Higher Education, Vol. 8 No. 1, pp. 2542-25417.

Jones, C. (2019), "A signature pedagogy for entrepreneurship education”, Journal of Small Business and Enterprise Development, Vol. 26 No. 2, pp. 243-254.

Jones, S. (2014), "Gendered Discourses of Entrepreneurship in UK Higher Education: The Fictive Entrepreneur and the Fictive Student", International Small Business Journal, Vol. 32 No. 3, pp. 237-258.

Jones, P, Pickernell, D., Fisher, R. and Netana, C. (2017), "A Tale of Two Universities: Graduates Perceived Value of Entrepreneurship Education", Education + Training, Vol. 59 No. 7/8, pp. 689-705.

Kassean, H., Vanevenhoven, J., Liguori, E. and Winkel, D. E. (2015), "Entrepreneurship education: a need for reflection, real-world experience and action", International Journal of Entrepreneurial Behavior \& Research, Vol. 21 No. 5, pp. 690-708.

Klapper, R. and Refai, D. (2015) A Gestalt model of entrepreneurial learning, Entrepreneurial Learning: The Development of New Perspectives in Research, Education and Practice. Routledge Studies in Entrepreneurship. Routledge: London.

Kolb, D.A. (1984) Experiential Learning: Experience as the Source of Learning and Development. Prentice Hall: Englewood Cliffs, New Jersey.

Krueger, N. (1993), "The Impact of Prior Entrepreneurial Exposure on Perceptions of New Venture Feasibility and Desirability", Entrepreneurship: Theory and Practice, Vol. 18 No.

1, pp. 5-21.

Krueger, N., Reilly, M. and Carsrud, A. (2000), "Competing models of entrepreneurial intentions", Journal of Business Venturing, Vol. 15, pp. 411-532.

Kuratko, D. (2017). Entrepreneurship: Theory, Process, Practice, (10th ed.) Mason, OH: Cengage/South-Western Publishers.

Kuratko, D., and Morris, M.H. (2017), "Examining the Future Trajectory of Entrepreneurship", Journal of Small Business Management, Vol. 56 No. 1, pp. 11-23.

Lackéus, M. (2014), “An emotion based approach to assessing entrepreneurial education", The International Journal of Management Education, Vol. 12 No. 3, pp. 374-396.

Lave, J. and Wenger, E. (1991) Situated learning: legitimate peripheral participation. Cambridge University Press: Cambridge.

Lilischkis, S., Volkmann, C. and Halbfas, B. (2015) Supporting the Entrepreneurial Potential of Higher Education: Final Report European Commission, [online] http://sephe.eu/fileadmin/sephe/documents/sephe_final-report_2015-06-30_v1.10.pdf.

Lorz, M., Mueller, S. and Volery, T. (2013), "Entrepreneurship Education: A Systematic 
Review of the Methods in Impact Studies”, Journal of Enterprising Culture, Vol. 21 No. 2, pp. 123-151.

Milner, S., Cousins, W. and McGowan, I. (2016), "Does All Work and No Play Make a Dull Graduate? Perceptions of Extra-curricular Activities and Employability", Journal of Perspectives in Applied Academic Practice, Vol. 4 No. 1, pp. 13-18.

Morris, M. Webb, J. Fu, J. and Singhal, S. (2013), "A Competency-Based Perspective on Entrepreneurship Education: Conceptual and Empirical Insights", Journal of Small Business Management, Vol. 51 No. 3, pp. 352-369.

Mueller, S. and Anderson, A. (2014), "Understanding the Entrepreneurial Learning Process and its Impact on Students' Personal Development: A European Perspective”, International Journal of Management Education, Vol. 12 No. 3, pp. 500-511.

Nabi, G., Walmsley, A., Liñán, F., Akhtar, I. and Neame, C. (2016), "Does Entrepreneurship Education in the First Year of Higher Education Develop Entrepreneurial Intentions? The Role of Learning and Inspiration", Studies in Higher Education, Vol. 43 No. 3, pp. 452-467.

Nabi, G., Linan, F., Fayolle, A., Kreuger, N. and Walmsley, A. (2017), "The Impact of Entrepreneurship Education in Higher Education", Academy of Management Learning and Education, Vol. 16 No. 2, pp. 1-23.

Neck, H.M. and Corbett, A.C. (2018), "The Scholarship of Teaching and Learning Entrepreneurship", Entrepreneurship Education and Pedagogy, Vol. 1 No. 1, pp. 8-41.

Neck, H.M. and Greene, P.G. (2011), "Entrepreneurship Education: Known Worlds and New Frontiers", Journal of Small Business Management, Vol. 49 No. 1, pp. 55-70.

Neck, H.M., Greene, P.G. and Brush, C.G. (2014) Teaching entrepreneurship: A practice based approach, Edward Elgar Publishing: Cheltenham UK.

Neergard, H., Blenker, P., Frederiksen, S.H.H., Korsgaard, S., Muller, S. and Thrane, C. (2012), "Entrepreneurship as everyday practice: towards a personalized pedagogy of enterprise education", Industry and Higher Education, Vol. 26 No. 6, pp. 417-430.

Office of National Statistics (ONS) (2017). Population Estimates for UK, England and Wales, Scotland and Northern Ireland 2016 .https://www.ons.gov.uk/peoplepopulationandcommunity/populationandmigration/population estimates/bulletins/annualmidyearpopulationestimates/mid2016 accessed April. 18, 2019.

Oosterbeek, H., van Praag, M. and Ijsselstein, A. (2010), The Impact of Entrepreneurship Education on Entrepreneurial Skills and Motivation, European Economic Review, Vol. 54 No. 3, pp. 442-454.

Padilla-Angulo, L. (2017), "Student associations and entrepreneurial intentions", Studies in Higher Education, Vol. 44 No. 1, pp. 45-58.

Patton, M. (1990). Qualitative Evaluation and Research Methods, Sage: Beverly Hills, CA. Pittaway, L. and Cope, J. (2007a), "Entrepreneurship education: A systematic review of the evidence", International Small Business Journal, Vol. 25 No. 5, pp. 477-506.

Pittaway, L. and Cope, J. (2007b), "Simulating entrepreneurial learning; integrating experiential and collaborative approaches to learning", Management Learning, Vol. 38 No. 2, pp. 211-233.

Pittaway, L. and Edwards, C. (2012), “Assessment: examining practice in entrepreneurship education", Education+ Training, Vol. 54 No. 8/9, pp. 778-800.

Pittaway, L., Rodriguez-Falcon, E., Aiyegbayo, O. and King, A. (2011), "The role of entrepreneurship clubs and societies in entrepreneurial learning”, International Small Business Journal, Vol. 29 No. 1, pp. 37-57.

Pittaway, L., Gazzard, J., Shore, A. and Williamson, T. (2015), "Student clubs: experiences in entrepreneurial learning", Entrepreneurship and Regional Development, Vol. 27 No. 3/4, pp. $127-153$. 
Politis, D. (2005), "The Process of Entrepreneurial Learning: A Conceptual Framework", Entrepreneurship: Theory \& Practice, Vol. 29 No. 4, pp. 399-424.

Politis, D., Winborg, J., and Lindholm Dahlstrand, A. (2010), "Exploring the resource logic of student entrepreneurs", International Small Business Journal, Vol. 30 No. 6, pp. 659-683.

Preedy, S. and Jones, P. (2015), "An investigation into University extra-curricular enterprise support provision", Education + Training, Vol. 57 No. 8/9, pp. 992-1008.

Quality Assurance Agency (QAA) (2018). 'Enterprise and Entrepreneurship Education. Guidance for UK Higher Education Providers'.: http://www.qaa.ac.uk/en/Publications/Documents/Enterprise-and-entrpreneurship-education2018.pdf. Accessed March. 8, 2019.

Rae, D. (2004), "Practical theories from entrepreneurs' stories: discursive approaches to entrepreneurial learning", Journal of Small Business and Enterprise Development, Vol. 11 No. 2, pp. 195-202.

Rae, D., Martin, L., Antcliff, V. and Hannon, P. (2012), "Enterprise and entrepreneurship in English Higher Education: 2010 and beyond", Journal of Small Business and Enterprise Development, Vol. 19 No. 3, pp. 380-401.

Rideout, E.C. and Gray, D. O. (2013), "Does entrepreneurship education really work? A review and methodological critique of the empirical literature on the effects of university-based entrepreneurship education", Journal of Small Business Management, Vol. 51 No. 3, pp. 329351.

Ritchie, J., Lewis, J., McNaughton Nicholls, C. and Ormston, R. (2013) Qualitative Research Practice, $2^{\text {nd }}$ Edition, Sage: London.

Rubin, R.S., Bommer, W.H. and Baldwin, T.T. (2002), "Using extracurricular activity as an indicator of interpersonal skill: Prudent evaluation or recruiting malpractice?", Human Resource Management, Vol. 41 No. 4, pp. 441-454.

Saldana, J. (2013) The Coding Manual for Qualitative Researchers, $2^{\text {nd }}$ Edition, Sage: London. Shinnar, R.S., Hsu, D.K., Powell, B.C. and Zhou, H. (2018), "Entrepreneurial Intentions and Start-ups: Are Women or Men more likely to enact their Intentions?" International Small Business Journal, Vol. 36 No. 1, pp. 60-80.

Shirokova, G., Osiyevskyy, O., Morris, M.H. and Bogatyreva, K. (2017), "Expertise, university infrastructure and approaches to new venture creation: assessing students who start businesses", Entrepreneurship \& Regional Development, Vol. 29 Nos. 9/10, pp. 912-944.

Strauss, A. and Corbin, J. (1998), Basics of Qualitative Research Techniques and Procedures for Developing Grounded Theory, $2^{\text {nd }}$ Edition. Sage Publications: London.

Taylor, D. and Thorpe, R. (2004), "Entrepreneurial learning: a process of co-participation", Journal of Small Business and Enterprise Development, Vol. 11 No. 2, pp. 203-211.

Thrane, C., Blenker, P., Korsgaard, S. and Neergaard, H. (2016), "The promise of entrepreneurship education: reconceptualizing the individual-opportunity nexus as a conceptual framework for entrepreneurship education", International Small Business Journal, Vol. 34 No. 7, pp. 905-924.

Toutain, O., Fayolle, A., Pittaway, L. and Politis, D. (2017), "Role and impact of the environment on entrepreneurial learning", Entrepreneurship \& Regional Development, Vol. 29 Nos. 9/10, pp. 869-888.

Tseng, C. (2013), "Connecting self-directed learning with entrepreneurial learning to entrepreneurial performance", International Journal of Entrepreneurial Behavior \& Research, Vol. 19 No. 4, pp. 425-446.

Van Gelderen, M. (2010), "Autonomy as the Guiding Aim of Entrepreneurship Education", Education + Training, Vol. 52 No. 8/9, pp. 710-721.

Vanevenhoven, J. and Drago, W.A. (2015), "The Structure and Scope of Entrepreneurship Programs in Higher Education around the World". In Rae, D. and Wang, C.L. (Eds.), 
Entrepreneurial Learning: New Perspectives in Research, Education and Practice, Routledge: UK.

Vanevenhoven, J. and Liguori, E. (2013), "The Impact of Entrepreneurship Education:

Introducing the Entrepreneurship Education Project", Journal of Small Business Management, Vol. 51 No. 3, pp. 315-328.

Vygotsky, L. S. (1978) Mind in society: The development of higher psychological processes, Harvard University Press: Massachusetts, USA.

Wang, C.L. and Chugh, H. (2014), "Entrepreneurial learning: Past research and future challenges", International Journal of Management Reviews, Vol. 16 No.1, pp. 24-61.

Watson, K. and McGowan, P. (2019), "Rethinking competition-based entrepreneurship education in higher education institutions: Towards an effectuation-informed coopetition model", Education + Training, Vol. 62 No. 1, pp. 31-46.

Watson, K., McGowan, P. and Cunningham, J. (2018), "An exploration of the Business Plan Competition as a methodology for effective nascent entrepreneurial learning", International Journal of Entrepreneurial Behavior \& Research, Vol. 24 No. 1, pp. 121-146.

Zapkau, F.B., Schwens, C. and Kabst, R. (2017), "The Role of Prior Entrepreneurial Exposure in the Entrepreneurial Process: A Review and Future Research Implications", Journal of Small Business Management, Vol. 55 No. 1, pp. 56-86.

Zozimo, R., Jack, S. and Hamilton, E. (2017), "Entrepreneurial Learning from Observing Role Models”, Entrepreneurship \& Regional Development, Vol. 29 No. 9/10, pp. 889-911. 


\begin{tabular}{|l|l|}
\hline Extracurricular Enterprise Activity & No. of respondents \\
\hline Networking event & 52 \\
\hline Socialising & 43 \\
\hline Guest Speaker event & 38 \\
\hline Mentoring/coaching session & 25 \\
\hline Business Competition & 12 \\
\hline Trading Practice & 11 \\
\hline Other & 7 \\
\hline
\end{tabular}

Table 1. Types of extracurricular enterprise activities respondents participated in $(n=78)$

\begin{tabular}{|l|l|}
\hline $\begin{array}{l}\text { Elements of experiential learning (Kolb, } \\
\text { 1984) }\end{array}$ & $\begin{array}{l}\text { Outcome of engaging in extracurricular } \\
\text { enterprise activities }\end{array}$ \\
\hline Having experiences & $\checkmark$ \\
\hline Reflection on experience & $\mathbf{x}$ \\
\hline Abstract conceptualisation & $\mathbf{x}$ \\
\hline Active experimentation & $\checkmark$ \\
\hline
\end{tabular}

Table 2. Alignment of experiential learning theory and learning outcomes of engaging in extracurricular enterprise activities 